\title{
THE ADVANCED COGNITIVE ABILITIES OF THE MULTIDIMENSIONAL PERSON
}

\author{
Yalalov Farit Gabtelovich \\ Tolstoy Institute Of Philology And Intercultural Communication Of Kazan Federal University, Russia \\ State Institution, Tatarstan Academy Of Sciences, Russia \\ Yalalov51@Mail.Ru \\ Kashapova Aygul Razifovna \\ Tolstoy Institute Of Philology And Intercultural Communication Of Kazan Federal University, Russia \\ Gromova Chulpan Raesovna \\ Institute Of Psychology And Education Of Kazan Federal University, Russia
}

\begin{abstract}
Research objective is to determine dependence of professional multidimensionality on the person'scognitive abilities, to develop an essence and a cognitive orientation of multidimensional thinking, to study cognitive opportunities of memory and attention. The leading method of research is the system analysis of essence of multidimensional thinking. In the work the theoretical materials about multidimensional thinking published in the press, results of the experimental studies connected with detection of functionality of memory, attention and thinking were used. The cognitive basis of professional multidimensionality is made by the multidimensional thinking directed to extraction of new meanings by simultaneous actualization and correlation of several local semantic spaces. Nizhnekamsk office of Gertsen university UNESCO department research associates under the leadership of the author of this article made a contribution to research of cognitive bases of multifunctionality, multitasking and integrity. The results received in article can be used forworking out the technology of the expert's professional self-development based on multidimensional thinking and the advanced cognitive abilities.
\end{abstract}

Keywords: multidimensional thinking, multidimensional person, professional multidimensionality, multidimensional competences.

\section{INTRODUCTION}

Relevance of research of the multidimensional person'scognitive abilitiesis connected with studying of such phenomenon as professional multidimensionality - abilities of the specialist to combine performance of several functions, to match the simultaneous solution of several production tasks, to correlate several directions (approaches) and the local semantic spaces corresponding to them. We call the competences connected with multifunctionality, multitasking and integrity as competences of the multidimensional person or multidimensional competences (Yalalov, 2013). Professional multidimensionality becomes competitive advantage of the modern specialist today. The new prospects for self-development and selfimprovement connected with professional multidimensionality open before the multidimensional specialist (Bordovsky, 2013).

Questions of education of the multidimensional person, formation of multidimensional thinking are reflected in works of many authors. So Y. Kozeletsky marks out five distinctive features in education of the multidimensional person: formation of a research position; implementation of multidimensional approach to training; structuring knowledge from various areas, their code conversion into larger units; realization of subjectivity in the teaching and educational activity, recognizing the person not only as the learning subject but also as the subject generating new knowledge; inspiring motivation to self-education on the basis of multidimensional thinking development (Kozeletsky, 1991). The personality in the B. Morgun's multidimensional concept is considered as actively mastering and consciously transforming the 
nature, society and own identity person which has a unique dynamic ratio of space-temporal orientations, need-willed emotions, substantial orientations and levels of experience mastering, multidimensional forms of realization of the activity (Morgun, 1992). On the basis of the logical-semantic models V. Shteynbergdeveloped the multidimensional didactic tools aimed at the development of the person'smultidimensional abilities (Shteynberg, 2002).Using the synergetic principles of openness, integrity and variety, A. Ostapenko created the theory and technology of modeling of multidimensional pedagogical reality (Ostapenko, 2007). The multidimensional model of mathematical training of the teacher was realized in A. Dorofeyev'sworks (Dorofeev, 2011).

During the research of cognitive bases of professional multidimensionality Nizhnekamsk office of Gertsen university UNESCO department research associatesinitiallyproceeded from the fact that for combination of several functions, matching the simultaneous solution of several tasks, integration of several directions (approaches) it was necessary to involve into work at the same time both cerebral hemispheres. Such qualities as rationality and logicality, ability to make cause-and-effect relationships, to perceive separate details of objects and the phenomena, to analyze and structure are connected with work of the left hemisphere (abstract and logical thinking). Intellectual qualities of opposite sense are connected with right hemisphere thinking (art and figurative): irrationality and illogicalness, ability to perceive holistically objects and the phenomena, ability to act intuitively, to listen to an internal voice, to follow the images created by imagination (Auhadeeva et al, 2015). The result of combination of two thinking types -left hemisphere and right hemisphere -represents a certain synthesis of mind and imagination, in which the logic is supported by intuition and vice versa. The specialists combining two types of thinking have great intuition, high creative potential, emotional perception, well developed intelligence, analytical thinking, enterprise, ability to ingenious enlightenments (Fakhrutdinova, Konopatskaya, 2015). At the sametime we have faced functional limitation of classical (linear) thinking. For combination of several functions, matching the simultaneous solution of several tasks, integration of several directions (approaches) the thinking of the person has to be multidimensional (nonlinear). We determined the multidimensional specialist's cognitive abilities through development of essence of multidimensional thinking, detection of his cognitive advantages in comparison with classical (linear) thinking.

\section{MATERIALS AND METHODS}

A research objective is to determine dependence of professional multidimensionality on the person'scognitive abilities, to develop an essence and a cognitive orientation of multidimensional thinking, its advantages over classical thinking, to disclose cognitive opportunities of memory and attention. A methodological basis of the research is the system structured approach. The leading method of our research is the system analysis by means of which ontologic bases of thinking have been revealed. Nizhnekamsk office of Gertsen university UNESCO department research associates made a contribution to research of cognitive bases of professional multidimensionality. As a result of the comparative analysis we systematized the principles of linear and nonlinear thinking, their cognitive orientation was defined, substantial and intrinsic characteristics of multidimensional thinking were revealed and formulated.

L. Bogataya's theoretical materials about multidimensional thinking (Bogataya, 2010), results of the experimental studies connected with detection of functionality of memory, attention and thinking were used in work. When studying cognitive opportunities of the structured information, determining a role of contextual associations and contextual reminders in memory functioning, results of experimental studies of such authors as G. Cook, T. Meeks, A. Clark-Foos, P. Merritt, R. March were used (Cook et al, 2013). According to M. Chikzentmikhay at simultaneous performance of two kinds of activity the expense of mental energy considerably increases. Energy is spent for maintenance in excitation stateof two centers of a brain, and also for ensuring continuous interaction between them (Csikzentmihalyi, 1990). At simultaneous perception of a large number of objects, as show M. Bulatova, I. Utochkin, distortion of individual object perception occurs (Bulatova, Utochkin, 2013). On the other hand, materials of empirical research confirm the fact of automation of attention as main effect of learning. Due to automationof searchingprocesses the volume of intellectual effort decreases and there is a certain stock for the distributed attention, i.e. performance of additional functions (Shiffrin, Schneider, 1977).

Submit Date: 10.05.2016, Acceptance Date: 24.06.2016, DOI NO: 10.7456/1060JSE/044 


\section{RESULTS}

1. The basis of professional multidimensionality is made by such advanced cognitive ability of the person as the multidimensional thinking directed to extraction of new meanings by simultaneous actualization and correlation of several local semantic spaces. Essential characteristics, in particular elementary units and ontologic bases, the main principles and logical instruments of classical and multidimensional thinking are presented in table 1.

Table 1.

\begin{tabular}{|c|c|c|}
\hline $\begin{array}{c}\text { Essentialcharacteristicsoft } \\
\text { hinking }\end{array}$ & Classical (linear) thinking & $\begin{array}{c}\text { Multidimensional (nonlinear) } \\
\text { thinking }\end{array}$ \\
\hline $\begin{array}{l}\text { Dimension of semantic } \\
\text { space }\end{array}$ & Three-dimensional & Four and more- dimensional \\
\hline Ontologic bases of thinking & $\begin{array}{l}\text { Objects of the displayed } \\
\text { world and direct } \\
\text { abstractions (abstraction of } \\
\text { the first level) appearing } \\
\text { from their understanding }\end{array}$ & $\begin{array}{l}\text { Objects of the displayed world, the } \\
\text { abstractions of the first level and new } \\
\text { meanings generated by the } \\
\text { multidimensionally thinking subject } \\
\text { (abstraction of the second level) }\end{array}$ \\
\hline $\begin{array}{l}\text { Elementary units of } \\
\text { thinking }\end{array}$ & $\begin{array}{l}\text { Concept which fixes signs } \\
\text { and properties of the } \\
\text { displayed world }\end{array}$ & $\begin{array}{l}\text { The concept directed to formation of } \\
\text { semantic variety of constantly } \\
\text { changing world }\end{array}$ \\
\hline $\begin{array}{l}\text { Cognitive orientation of } \\
\text { thinking }\end{array}$ & $\begin{array}{l}\text { Establishment of cause-and- } \\
\text { effect regularities by means } \\
\text { of formal logic methods }\end{array}$ & $\begin{array}{l}\text { Extraction of new meanings on the } \\
\text { basis of simultaneous actualization } \\
\text { and correlation of several local } \\
\text { semantic spaces }\end{array}$ \\
\hline Main principles of thinking & $\begin{array}{l}\text { Determinism, logicality, } \\
\text { causalconditionality }\end{array}$ & $\begin{array}{l}\text { Terminizm, hierarchy and symmetry, } \\
\text { spontaneity, accident }\end{array}$ \\
\hline Instruments of thinking & $\begin{array}{l}\text { Methods of formal logic: } \\
\text { analysis and synthesis, } \\
\text { induction and deduction, } \\
\text { comparison and marking } \\
\text { out, systematization and } \\
\text { generalization }\end{array}$ & $\begin{array}{l}\text { Sense-making procedures: } \\
\text { clarification andsense-display, } \\
\text { fixation and sense-use }\end{array}$ \\
\hline
\end{tabular}

2. Such cognitive abilities of the person as structuredness of memory, multivector nature of attention, flexibility of thinking are considered to be more adapted for manifestation of multifunctionality, multitasking and integrity. Cognitive bases of professional multidimensionality are presented in table 2 .

3. The structured memory represents the improved for multidimensionality manifestation form of storing and reproduction of actual information on the basis of contextual associations and contextual reminders. 4. The distributed multivector attention is directed to actualization of information, necessary for manifestation of multidimensionality, at the same time - to implementation of continuous information exchange between several local semantic spaces.

5. Flexibility of thinking is aimed at providing of information actualization speed, sufficient for multidimensionality manifestation, and sufficient frequency of attention switching from one local semantic space to another.

Table 2.

\begin{tabular}{|c|c|l|}
\hline Multidimensionalcompetences & $\begin{array}{c}\text { Contentofmultidimensionalit } \\
\mathbf{y}\end{array}$ & $\begin{array}{c}\text { Cognitivebasesofmultidime } \\
\text { nsionality }\end{array}$ \\
\hline Multifunctionality & $\begin{array}{c}\text { Ability to combine } \\
\text { performance of several } \\
\text { functions }\end{array}$ & $\begin{array}{l}\text { Multidimensional thinking }+ \\
\text { structuredness of memory }+ \\
\text { multivector nature of }\end{array}$ \\
attention + flexibility of \\
thinking.
\end{tabular}




\begin{tabular}{|l|c|c|}
\hline Integrity & $\begin{array}{c}\text { Ability to correlate several } \\
\text { directions, the local semantic } \\
\text { spaces }\end{array}$ & \\
\hline
\end{tabular}

\section{CONCLUSION AND DISCUSSIONS}

Multidimensional thinking is more advanced thinking which has more dimensions than linear thinking, it has at least one unit more. The multidimensional thinking is four and more dimensional. Additional dimensionis used for a meaning formation, i.e. generation of new meanings in the course of cogitative activity of the subject. Unlike the linear thinking focused on establishment of cause-and-effect regularities, the multidimensional thinking is directed to detection and extraction of new meanings. By means of multidimensional procedures (sense- display, sense-fixation, sense-use, etc.) the thinking subject is capable to actualize and integrate at the same time several local semantic spaces, and on their basis - to generate new meanings(Bogataya, 2013).

Elementary unit of linear thinking is the concept which accurately fixed meaning allowing to use it equally in various cogitative procedures. The concept acts as fundamental unit of multidimensional thinking. Any concept has a name to which there can correspond the set of meanings. Objects of the displayed world, abstractions of the first level, and also the new meanings generated by the multidimensionally thinking subject (abstraction of the second level) act as the ontologic basis of multidimensional thinking. The new sense can'tappear without person, without his conscious cogitative activity.

Structuredness of memory. The structured person as usual arranges everything according to a wellthought-out system, in strict order. The structured people quicker than others take their bearings in difficult situation, make the correct decision and start actions immediately. The unstructured person is in confusion for some time in an uncertain situation: he doesn't know how to start out. The reason is that his memory, better to say the information from his memory isn't structured appropriately.

Contextual associations and contextual reminders provide the reliable mechanism of storing and reproducing of the structured information. By the analysis of experimental works results devoted to research of contextual associations and contextual reminders functionality (Cook et al, 2013), we came to the formulation of the memory which was more adapted for multidimensionality manifestation.

Multivector nature of attention. The attention advances actions in any business. It has organizing and mobilizing influence on physical and mental activity of the person. Pedagogical process, as we know, represents the joint - divided activity: the training activity of the teacher and cognitive activity of pupils happens in one place, at one time. The skilled teacher capable to distribute the attention integrate into a lesson simultaneously several types of the training and controlling activity (Gromova, Alimbekov, 2015). At the stage of review he, for example, gives a test to all class in two variants. This time four pupils are making an individual test. Until pupils are busy with test, the teacher checks homework of all class, at the same time controls correctness of doing of four children's individual tasks. After completion of the test by pupils, the correct answers appear on the screen. Pupils verify their works with the correct answers on the screen, correct errors. Thanks to a combination of three kinds of activity, labor productivity of the multitask teacher considerably exceeds labor productivity of the teacher working according to the linear scheme (Yalalov, Kaiumova, 2015). Flexibility of thinking. For implementation of multidimensional cogitative activity the person should switch constantly from one local semantic space to another. Without switching there is no multidimensional thinking.

During research of cognitive bases of professional multidimensionality we managed to open essence of the multidimensional thinking which is more difficult in comparison with classical thinking, having essential cognitive advantages. If the classical thinking is focused on making cause-and-effect regularities, so the multidimensional thinking, which is the cornerstone of professional multidimensionality, is directed to generation of new meanings by simultaneous actualization and 
correlation of several local semantic spaces. For simultaneous actualization and correlation of several semantic spaces cognitive abilities of thinking, memory and attention of the person have to be improved. As we have received, such increased abilities of the person as structuredness of memory, multivector nature of attention, flexibility of thinking were more adapted for manifestation of multifunctionality, multitasking and integrity.

The results received during our research have an applied orientation; they can be used in development of technology of the specialist's professional self-development on the basis ofmultidimensional thinking formation and cognitive abilities development.

\section{REFERENCES}

Yalalov F.G. (2013) Professionalnaya mnogomernost [Professional multidimensionality]. Kazan: Center of innovative technologies., 180 p. (in Russ.)

Bordovsky A.G. (2013) [The new opportunities connected with professional multidimensionality] Professionalnaya mnogomernost [Professional multidimensionality]. Kazan: Center of innovative technologies., pp. 3-6. (in Russ.)

Kozeletsky Yu. (1991) Chelovek mnogomernyj [Multidimensional person]. Kiev: Lybid., 288 p. (in Russ.)

Morgun V.F. (1992) [Concept of multidimensional development of the personality and its appendix] Filosofskaya i sociologicheskaya mysl [Philosophical and sociological thought]. Kiev., No 2, pp. 27-40. (in Russ.)

Shteynberg V.E. (2002) Didakticheskie mnogomernye instrumenty: teoriya i praktika [Didactic multidimensional tools: theory and practice]. Mockow: National education., 304 p. (in Russ.)

Ostapenko A.A. (2007) Modelirovanie mnogomernoj pedagogicheskoj realnosti. Teoriya i tekhnologii [Modeling of multidimensional pedagogical reality. Theory and technologies]. Mockow: National education., 384 p. (in Russ.)

Dorofeev A.V. Mnogomernaya matematicheskaya podgatovka budushchego pedagoga. Dokt. Diss. [Multidimensional mathematical training of future teacher. Doct. Diss.] Kazan, 2011. 389 p. (in Russ.)

Auhadeeva L.A., Yarmakeev I.E., Aukhadeev A.E. (2015) Gender Competence of the Modern Teacher. International Education Studies. Vol. 8, No. 2; doi:10.5539/ies.v8n2p32

Fakhrutdinova R.A., Konopatskaya E.A. (2015) Formation of Common Cultural Competences in the Students-Future Teachers of Foreign Languages During the Process of Professional Training at University. The Social Sciences 10(7), pp. 1768-1772.

Bogataya L.N. (2010) Na puti k mnogomernomu myshleniyu [On the way to multidimensional thinking]. Odessa: Printing house., 372 p. (in Russ.)

Cook G. I., Meeks T. J., Clark-Foos A., Merritt P.S., March R.L. (2014) The Role of Interruptions and Contextual Associations in Delayed-Execute Prospective Memory. Applied Cognitive Psychology. Vol. 28, pp. 91-103.

Csikzentmihalyi M. Flow: The Psychology of Optimal Experience. N.Y.: Harper and Row, 1990. 330 p. Bulatova M. E., Utochkin I.S. (2013) [Perceiving the Size of Individual Objects in an Ensemble under Focused and Distributed Attention]. Psihologiya. ZHurnal Vysshej shkoly ehkonomiki. Vol. 10. No. 3. P. 44-53. (in Russ.)

Shiffrin R., Schneider W. (1977) Conrolled and automatic human information processing: 2. Perceptual learning, automatic attending a general theory. Psychological Review., V. 84. No. 2. P. 127-190.

Bogataya L.N. [Philosophy of the multidimensional person]. Mezhdunarodnaya nauchnoobrazovatel'naya konferenciya "Mnogomernost' i celostnost' cheloveka $\mathrm{v}$ filosofii, nauke i religii" [Multidimensionality and integrity of the person in philosophy, science and religion. International scientific education conf.]. Kazan: Kazan University., 2012, pp. 219-226. (in Russ.)

Gromova C.R., Alimbekov A. (2015) Egocentrism and Development of Students Identity (On the Example of Studying of Future Teachers). International Journal of Environmental and Science Education, Volume 10, Issue 4 Special Issue, pp. 571-578. DOI: 10.12973/ijese.2015.271a

Yalalov F.G., Kaiumova L.R. (2015) Psychological Bases of Professional Multidimensionality. The Social Sciences. Vol. 10 (6), pp. 883-887. DOI: 10.3923/sscience.2015.883.887. Abstract Fulltext PDF (accessed 2.04.2016). 